The Brock Review Volume 10 (2008)

(C) Brock University

\title{
A Grave Garden: Aritha van Herk's Calgary
}

\author{
Shelley Boyd \\ McGill Institute for the Study of Canada \\ McGill University
}

\begin{abstract}
In her long poem Calgary, This Growing Graveyard, Aritha van Herk presents the cemetery as a public garden of critical reflection within the rapidly changing urban environment of Calgary, Alberta. Foregrounding the simultaneous processes of growth and decay, van Herk suggests that the cemetery as garden becomes symbolic not only of the city's successive generations, but also of the ongoing creation, destruction, and recreation of the city's physical-cultural landscape. First published in 1987, Calgary, This Growing Graveyard captures the "boom and bust" economy of Calgary following the implementation of Canada's National Energy Program in 1980. Now in 2008, van Herk's poem turns prophetic as Calgarians experience the growing pains that coincide with a lucrative economy, mass migration, and urban sprawl.
\end{abstract}

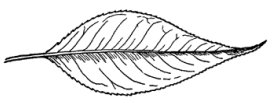

First published in 1987, Aritha van Herk's long poem Calgary, This Growing Graveyard captures the boom and bust economy of Calgary following the robust oil prices of the 1970s and the subsequent economic downturn after the implementation of Canada's National Energy Program in 1980. At that time, van Herk addressed the detrimental effects to the city's residents, the economy, and the urban landscape, making particular reference to Calgary's real-estate crash of the early 1980s. In the poem, van Herk uses the cemetery as a figurative model of the city in order to capture its sudden decline, and the subsequent isolation and effacement that Calgarians experience in their altered environment. The cemetery as a kind of growing and decaying garden, with its mixture of both permanent and impermanent components, becomes the most evocative symbol of Calgary's dynamic urban landscape and its participation in boom and bust cycles. For present-day Calgarywhich, over 20 years later, boasts a lucrative economy, a population growth-rate three times the national average, and the largest urban "footprint in North America" with its over 800 square kilometres ${ }^{2}$ - van Herk's poem turns prophetic, ironically enough, in its depiction of the human alienation and depersonalization that continue to accompany a city undergoing rapid development. ${ }^{3}$ The enduring relevance of van Herk's poem for today's readers suggests that the urban environment is a veritable paradox in which decline and growth operate as simultaneous and related processes. A public garden of critical reflection, then, van Herk's cemetery model reveals that even within Calgary's artificial, highly constructed environment, the city is surprisingly "organic," making it a living and, therefore, dying place that reflects the transitory nature and fallible identities of its citizens.

At first glance, van Herk's focus on the cemetery seems a gesture toward a peaceful, green counterpart to the constructed landscape of the city, as cemeteries have a long association with the natural, the rural, and the urban fringes. Van Herk's original publication of her Calgary poem in the journal NeWest Review highlights this separation of the urban centre (where asphalt and concrete 
predominate) from the rural graveyard, as van Herk intersperses her text with several photographs of tombstones and graves, many of which are situated on the plains or in natural, overgrown settings. While van Herk's text describes a highly constructed, urban Calgary, the photographic images of rural graveyards create an unexpected visual contrast, which works to remind readers of the significant, if oftentimes overlooked, role of cemeteries within urban contexts. Historically, cemeteries have played a central role in the lives of urban residents by being formulated as kinds of public gardens. During the first half of the nineteenth century, landscape designer John Claudius Loudon (1783-1843) became a pivotal figure in promoting the beautification of England's cemeteries as public parks vital to cities. James Stevens Curl notes that with the rise of the garden cemetery movement, Loudon turned away from the unappealing crowded churchyards of his day, which had very little grass because of the frequency of internment and were used by nearby urban residents as convenient places for emptying chamber pots. ${ }^{4}$ Loudon's re-visioning of the cemetery included picturesque landscape gardening, the planting of trees and shrubs, the use of sculpture, and welltended grounds. In Loudon's view, cemeteries needed to possess restorative properties: "The burialplaces for the metropolis', he wrote, 'ought to be made sufficiently large to serve at the time as breathing places." " The conceptualization of the cemetery as a garden extends beyond its incorporation of popular design aesthetics, however, as this association evokes the notion of regeneration, and even the resurrection. In The Secret Cemetery, Doris Francis, Leonie Kellaher, and Georgina Neophytou note, "Through the creation of the cemetery in the form of a landscape garden, a harmony with nature was sought in death - a return to the lost Garden of Eden." "It is not surprising, then, that one way of referring to a burial ground or churchyard is the phrase "God's acre," which recalls the Corinthians reference to "God's seed-field', in which the bodies of the departed are 'sown."'7

In Canada, the beautification of cemeteries became a popular movement during the latter half of the nineteenth century, as prominent citizens and landscape architects worked to design these spaces. For Canadians, cemeteries became sites not simply for disposing of the dead, but rather for the public's enjoyment of natural beauty, outdoor recreation, and even education. Montreal's Mont Royal Cemetery, which was established in 1852, was originally defined as a rural retreat with a parklike setting. (See Figs. 1-2) This cemetery has long been situated in the heart of Montreal; over the past 150 years, the development and expansion of the city resulted in the complete surrounding of the burial grounds. In his study of Mont Royal Cemetery, historian Brian Young observes, "Significantly, the first Mount Royal charter utilized the terms "public cemetery and garden.", Undulating paths, groupings of trees, and the visible contours of the natural landscape made for a "Romantic vision" inspired by Capability Brown's picturesque aesthetics." In A History of Canadian Gardening, Carol Martin reveals that cemeteries were such popular retreats for urban dwellers from the late nineteenth to early twentieth centuries that civic planners worked to promote access to these parks: Mount Pleasant Cemetery in Toronto was "a favourite place for family outings and picnics. Before long the city extended the streetcar line ... so that Torontonians could enjoy holiday trips to the cemetery. (Brantford and Calgary were among the other cities that extended their streetcar lines for the same purpose)."10

Today, the City of Calgary continues to promote its cemeteries as green-spaces for its citizens, and its official website outlines what it perceives to be the function of these terrains: "The City of Calgary encourages passive use of cemetery grounds for walking, cycling, nature observation, and historical research." 11 By facilitating recreational activities and proximity to nature, the cemeteries seem separate from the hustle and bustle of urban life. In an article in Canadian Geographic, van Herk acknowledges the park-like status of cemeteries when she describes them as "ecosystems of peace, 
Figs. 1-2: Mont Royal Cemetery, Montreal, 2007 (Photos by Shelley Boyd)
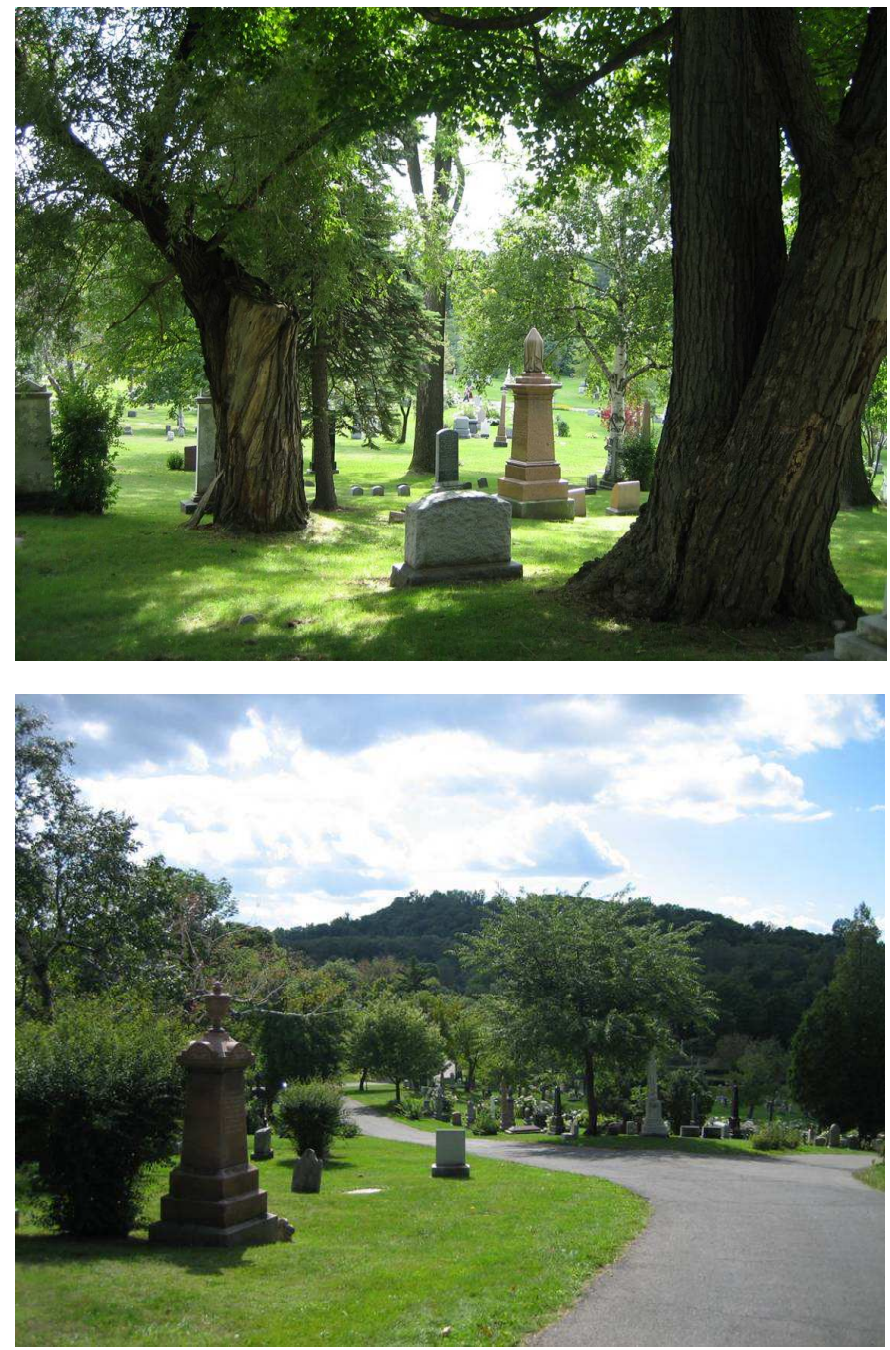

places to take respite from the hurry and wash of life"; here, artists such as stonemasons and gardeners create "beauty" in the natural environment. ${ }^{12}$ The City of Calgary's employment of the phrase "passive use" conveys, however, that within the city's cemeteries, there are social expectations pertaining to proper modes of conduct as these are not typical public parks. Moreover, the mention of historical research also reveals the cemeteries' potentially informative role in the conveyance of information to its visitors.

Since their conception, garden cemeteries have been considered to have an ameliorating effect on the urban dweller because they offer counterparts to (or green, rural retreats from) the urban environment, encourage dignified behaviour, and provide the opportunity for a kind of informal education. Young notes that the garden cemetery movement was founded upon a desire for social betterment: "Writing The Layout, Planting and Management of Cemeteries in 1843, ... John Claudius Loudon described them as schools 'of instruction in architecture, sculpture, landscape gardening, arboriculture, botany, and in those important parts of general gardening, neatness, order and high keeping." 13 Garden cemeteries in Canada, such as Mont Royal, "were the first recreational areas designed to inspire city dwellers: their mission was moral and educational." 14 This mission was undeniably taken to heart as one Montreal resident expressed the popular belief in Mont Royal 
cemetery's "refining influence" for the working classes by writing a letter of protest to the Gazette newspaper in 1863 that complained about temporary restrictions that curbed the public's access to the cemetery grounds. ${ }^{15}$

While the history of garden cemetery design suggests that cemeteries are valued green-spaces, in practice these repositories of the past have oftentimes been deemed inconsequential and inconvenient when it comes to urban development and the need to appropriate space that accommodates the needs of the present (living) population. The gradual displacement of the dead because of expansion and growth is quite typical of urban centres, and in his study of memorial architecture, Ken Worpole observes that many European cities have literally been erected over graves. During the nineteenth century, cities such as Paris and London had to contend with longestablished burial space when faced with urban development and new construction. When Préfet Haussmann suggested the closing or relocation of Paris' cemeteries in order to renovate the capital, "crowds protested in the streets with the cry Pas de cimitière, pas de citép"16 In the case of London, Worpole notes that human remains buried in many churchyards were relocated to mass graves in suburban cemeteries or were eventually buried beneath a constructed landscape as the city expanded: "It is estimated that over 6 million people lie buried in churchyards and cemeteries laid out in London between 1600 and 1900, only a minority of which are still in use. . . Wherever you walk in the City of London, the so-called 'square mile,' you are almost certainly walking over the dead." 17 As with any growing city continually in development, Calgary also has a history of relocating, and even building on top of, its burial grounds. In an article that traces Calgary's many reincarnations, writer Katherine Govier suggests that the city has a long history of effacing the past through its various stages of construction and appropriation of space. Govier writes that in the late 1800 s, the North West Mounted Police settled in what is now Calgary when they "built a log palisade and mud huts over Indian graves." 18 In the late twentieth century, Calgary's Chinese Cemetery, which is situated alongside the MacLeod Trail expressway and is the smallest cemetery in the city with only 1.4 hectares of land, was disturbed for the expansion of the city's infrastructure. The City of Calgary's website states, "In 1980, during the Light Rapid Transit (LRT) construction and the widening of MacLeod Trail, workers excavating near the cemetery unearthed thirty-nine bodies [in unmarked graves], which were later reburied in a mass grave." ${ }^{\prime 19}$

The problem with the relocation of cemeteries and their near-complete disappearance within an urban context is that, according to Worpole, "cities . . . are literally losing contact with the dead, particularly the recent dead," especially because "[f]ew, if any, modern urban planning models make reference to provision for burial or even memorial gardens." 20 A failure to acknowledge the importance of cemeteries when it comes to urban planning means that citizens not only lose a sense of the past, but also are not given the opportunity to reflect on the commonalities between the spaces occupied by the living and the dead. When it comes to the designing and theorizing of cemeteries, critics note that the methods of structuring cities and the ways in which humans understand and relate to their private homes have a profound bearing on the laying-out of cemeteries. Francis, Kellaher, and Neophytou argue, "Since ancient times, the architecture of the grave has mirrored society's thoughts about the dwellings of the living." 21 Language used to refer to burial sites obviously reflects this relationship: "necropolis refers to the dead as buried in or near a city, or perhaps as constituting a city in themselves. Cemetery does not refer to the dead at all. In classical Greek, the equivalent word meant simply a dormitory, and the English term then seems to imply a resting place or a sleeping place." 22 The similarity between our conceptualizations of the houses for the living and those of the deceased rests on the fact that just "[a]s the concept of home provides a focus, a grounding, a sense of place and of the past, so, too, can the burial places of kin establish and reinforce claims to rootedness and identity." ${ }^{23}$ Consider for a moment rural cemeteries such as Père-Lachaise and Montmarte in Paris that feature designs that mirror the environment of a 
village with its inhabitants housed in single-room dwellings for each resident and their families. (See Figs. 3-4) Worpole notes,

Many modern visitors of Père-Lachaise are initially overwhelmed by its street-pattern layout, especially those more used to the garden cemetery tradition. There are whole roads full of family 'houses,' elaborately designed and constructed, with many fine architectural and sculptural details, as if the occupants are still in the process of displaying their wealth, status, and good fortune to enjoy a smart address. $^{24}$

Although they may seem to be benign, green-retreats separated from daily life, cemeteries ultimately have much to communicate when it comes to society's relationship to space, the expression of identity, and the encoding of behaviour. These aspects all come into play in van Herk's poetic depiction of Calgary's cemeteries and in her use of the cemetery as a figurative model for the city of Calgary itself.

Van Herk's pairing of the city with the cemetery within her poem is an innovative and provocative gesture, particularly when one considers that the tendency is to displace or exclude places associated with death and the past when it comes to urban development. In light of the city's actual manipulation of its burial grounds, Calgary could be viewed as a place that has lost touch with the past because of its continual focus on present and future growth and its displacement of the dead. In her poem, however, van Herk asserts that death has not been entirely forgotten. By using the cemetery as a model for the city, van Herk suggests that Calgarians must confront on a daily basis the transitory nature of both their city and themselves through the urban environment that they have constructed, an environment where loss and renewal are ever-present.

When van Herk first published her poem in 1987, Calgarians had undergone rapid urban expansion, followed by a dramatic decline and exodus of people in search of employment and better prospects. In her poem, van Herk captures a city where office towers and private homes sit empty, creating a kind of ghost town or (empty) "cemetery" where few of the living, let alone the dead, choose to reside. But apart from Calgary's failing economy and loss of citizens, it is the city itself and especially its sprawl that van Herk sees as evocative of human nature and our undeniable connection with impermanence and effacement, despite our continual efforts to guarantee the contrary. In the boundless acres of uniform but separate suburban homes, van Herk sees Calgarians' dwelling spaces mirror the "homes" of the dead, as the individual graves of van Herk's Calgary tell one another to "move over" in their desire for individual property and space. ${ }^{25}$ With its westernfrontier mentality created in part through the Canadian government's nineteenth-century advertising slogan of "homes for millions," Calgary is a place where residents aspire to single-family homes on a plot of land. ${ }^{26}$ Van Herk notes that this desire for privacy and individuality ironically results in isolation and personal effacement when pursued in a sprawling urban context. The sprawl that van Herk described in 1987 continues to speak to contemporary readers who are familiar with Calgary's recent exponential population growth. When reflecting on his family's move out west from Toronto in a 2002 issue of Maclean's, Gordon Laird expresses the enduring idealism of the frontier mentality when he notes that even in the "megalopolis" that is now Calgary, he and his family could still afford to purchase a bungalow: "a mix between small town and big city that many Canadians hope for: our own little house on the prairie." 27 Unfortunately, the frontier idealism that underlies and fuels the urban sprawl of Calgary tends to overlook the social and environmental consequences of this kind of expansive construction. ${ }^{28}$ Past, present, and future readers of van Herk's poem may understand dramatically different aspects of the boom and bust cycles when it comes to Calgary's economy and 
Figs. 3-4: Montmarte Cemetery, Paris, France, 2007 (Photos by Shelley Boyd)
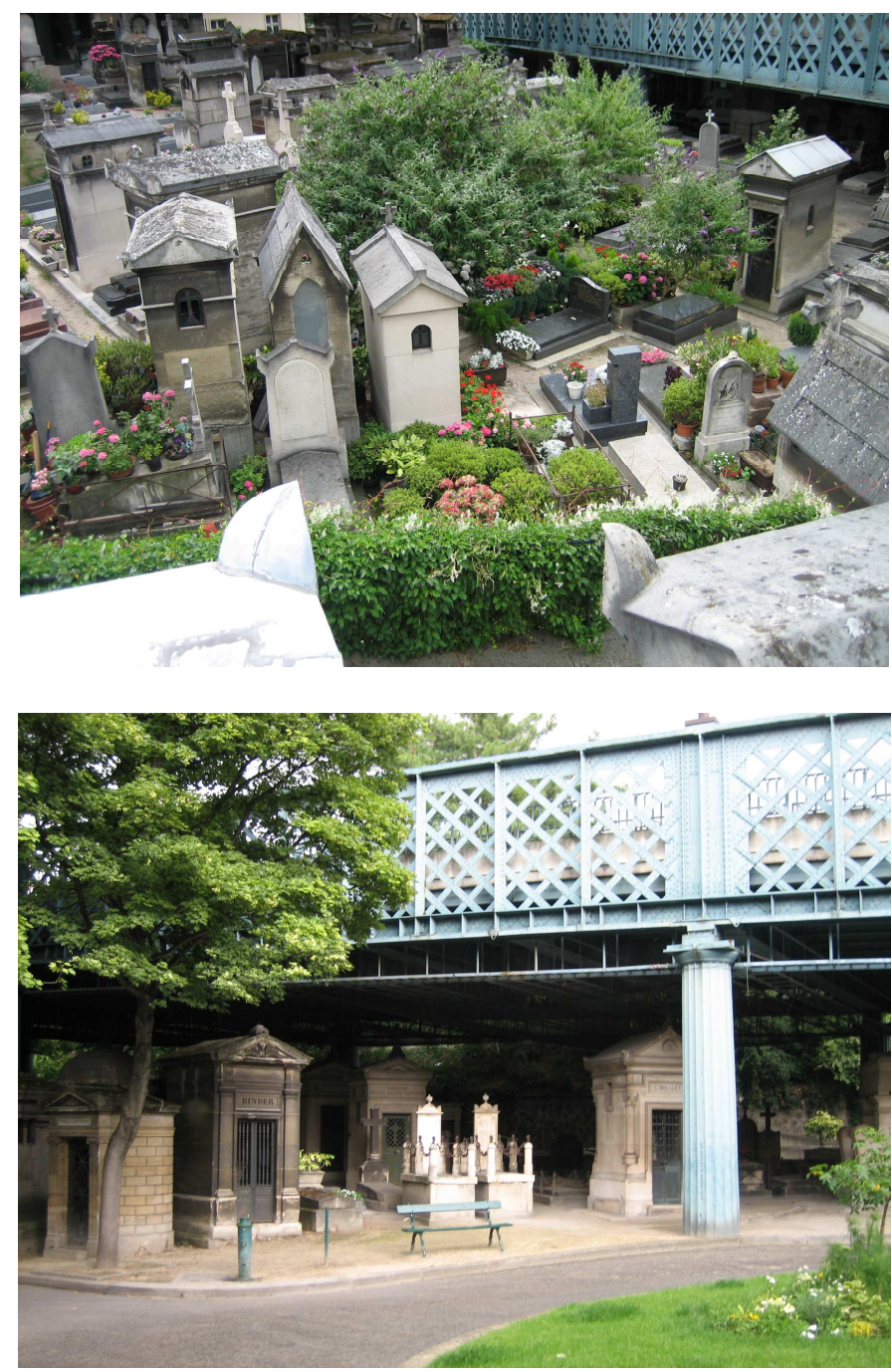

urban landscape, but despite this variable, van Herks' city-as-cemetery model maintains its relevance because of the insight it affords into the human condition in terms of our tenuous relationship to space, to time, and to each other.

At the opening of van Herk's poem, cemeteries, once situated on the urban fringes, now appear to be in a precarious position as the city expands to surround and overtake them. The expressway known as MacLeod Trail, which "push[es] itself souther and souther," slices through the Chinese Cemetery. ${ }^{29}$ This sprawling roadway and the citizens who use it every day appear disrespectful in the rush to urban expansion and the desire for rapid commutes as the speaker notes ironically, "You're driving over graves, that's when you know you're / on the right trail, / graves." 30 The rapid growth of Calgary's infrastructure has led to the loss or manipulation of historical resting places, but whether or not this disrespect for the past is "on the right trail," or correct path, in terms of where Calgary is heading is up for debate. Readers may assume that cemeteries are permanent and respected landscapes, but van Herk's speaker highlights the uncertain nature of these terrains within an evolving Calgary. On an 1883 map of the city, graves appear "right beside the RC Mission / . . later maps move the / RCs east." 31 The speaker contests this process of effacement, however, by 
stating that even within the city's shifting landscape, "stones will work their way to the surface, no matter how buried / and buried again." 32 In keeping with this assertion, the first page of van Herk's original NeWest publication, which begins with the section of the poem entitled "Quadrant One Stones" that focuses on cemeteries, overlays this early 1883 survey map of Calgary with a large grey rectangle. The grey shape is evocative of a tombstone asserting its previously "buried" presence in an undeniable way. Ultimately, the "growing" graves of Calgary refuse to be steam-rolled by expansion, as van Herk contends that these cemeteries, even in their over-crowded and crowded-out states, are deeply integrated within Calgary's urban landscape and, in fact, provide a critical lens for the consideration of it.

When trying to locate Calgary's cemeteries, the speaker of the poem encounters great difficulty until realizing that Calgarians categorize cemeteries as public gardens. Sites of internment, such as "Garden of Peace" and "Memorial Gardens," are "[m]arked / on the maps an odd tinted green" and set in relief in the urban context. ${ }^{33}$ The Calgary phonebook lists cemeteries under "City Parks and Recreation, no pun / intended." 34 The cemeteries apparently function as recreational space, but with the use of enjambment and an ironic tone, van Herk emphasizes the pun, implying that the city primarily views these sites as places of re-creation, or entry into the afterlife, rather than as places of loss, death, and decay. The speaker begins to shift perspective, however, after looking up the word "graveyard" in the Calgary phonebook: "And no mention of graveyards, that repository of the poor, a blank / space between gravel and greenhouse, though both might be / appropriate, connected." 35 In uncovering the phonebook's listing of cemeteries under "Parks" and its omission of "graveyards," the speaker exposes the fact that the somber and sober aspects of burial terrain are often effaced by the embellishing and comforting influence of the garden's association with the cemetery. The Oxford English Dictionary defines "graveyard" as simply a "burial-ground," while "cemetery" is distinguished in terms of its elements of design, being a "large public park or ground laid out expressly for the internment of the dead." When the listing for "graveyards" is left "blank" in the phonebook, there is an undeniable effacement of deceased residents whose resting places have been forgotten, removed, or covered over in the historical, spatial record of the city. But in naming her poem This Growing Graveyard, rather than This Growing Cemetery, van Herk indicates that she will not adhere to an over-idealization or benign rendering of the garden cemetery. Instead, van Herk works to re-incorporate and re-connect the dual features of a cemetery, as the blank space left in the phonebook where "graveyards" should appear connects both the living greenery (as suggested through "greenhouse"), and the inorganic, or "dead," materials of construction (as suggested through "gravel"). Moreover, in terms of her figurative model of the city-as-cemetery (or graveyard), van Herk opts for the word "graveyard" in her title because its denotation (unlike "cemetery") is more appropriate for her commentary on the visual appearance and effects of urban sprawl. In the growing graveyard of van Herk's Calgary, little or no aesthetic design seems to factor into the city's rapid construction of an unvarying landscape, as homes are assembled expediently in mass groupings or subdivisions. (See Fig. 5)

While van Herk highlights the characterization of Calgary's cemeteries as gardens, her objective is to problematize this idealization in order to bestow upon these gardens a critical and disruptive spatial role within the city. Throughout her poem, van Herk emphasizes that the literal and figurative gardening activity that takes place in a cemetery needs to be understood more fully in terms of its connection to burial and decay, rather than to notions of regeneration and eternal life. Reflecting on Calgary's cemeteries, the speaker states, "Rows and rows, a garden. / (a place for growing). ${ }^{, 36}$ Of course, these rows are not for plants, but for graves and tombstones. ${ }^{37}$ This kind of "growing" is delimited by decay and the need for its containment, as suggested through the parentheses that enclose the line. For the speaker, the garden is not an innocent venture, but rather intimately related to death and decline, as even fertilizer is created from pulverized animal bones 
gathered from Calgary's abattoirs. These "ground" remains represent "A different / coming to the garden, underground." 38 While cemeteries' association with the garden usually evokes the symbol of paradise and the realization of a transcendent state for the departed, the speaker here asserts a "different / coming to the garden" through a connection with the earth: the material reality of death. The bone meal entails a purely literal, rather than symbolic, return to the garden in the form of compost. Immediately following this garden reference, the speaker cries, "Ho" to readers in order to get their attention, but perhaps also to create a pun on the word "hoe," the implement used for cultivation and disturbing the soil. ${ }^{39}$ Following this call to attention, the speaker notes that in Calgary, undertakers are now known as funeral directors. Also, embalmers no longer have a place in the city's phonebook. All of these redefinitions and omissions with respect to the business of death reveal Calgarians' changing relationship to the past, as modern citizens seem increasingly removed from the sobering work and place of burial. In drawing attention to this effacement, however, van Herk's speaker models an active, rather than "passive use," of the city's cemeteries and attempts to reconnect with the past.

Fig. 5: Calgary's Sprawling Suburbs, 2008 (Photo by Keith Boyd)

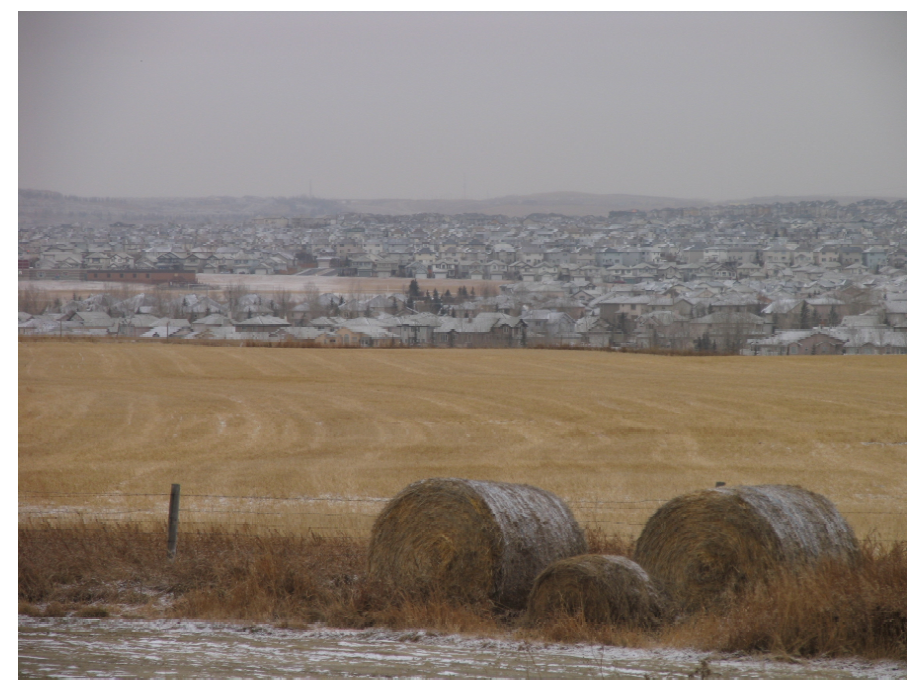

By complicating readers' perceptions of garden cemeteries, van Herk attributes to these spaces an informative dimension, albeit not in the polite, refining manner nineteenth-century garden cemetery designers originally intended. In van Herk's poem, the speaker clearly appreciates the cemetery's reputation for escape, admitting, "The graveyards of Calgary are your grottos." 40 While "grotto" suggests a "picturesque" or "agreeable retreat" and a "place of recreation," van Herk's cemetery grottos remain intimately associated with the city and force visitors to engage with the urban landscape, rather than retreat from it. When van Herk lists Calgary's cemeteries, she plays with the word, turning cemetery into "cementery." 41 The crossing over of words is but one gesture in a series that works toward aligning the city with the cemetery and highlighting their overlapping states and qualities. Van Herk's speaker draws attention to the proximity between city and cemetery in order to emphasize the spatial and ontological relationship between them. Queens Park Cemetery may appear "remote and placid above the city," 42 but "there in the / middle of split-level bungalows the cemetery partakes of / several coulees and a poplar bluff." 43 (See Fig. 6) Moreover, the remains of death appear to infiltrate the city and resist tidy containment as the speaker comments, "And the 
wind makes this a dusty city, your archeological longings / flung into your eyes, induced tears" as "ashes scattered and unburied settle here with the / mosquitoes and the rippled gusts of wind off the foothills." ${ }^{44}$ Here, death spreads across Calgary and touches its citizens, as burial grounds and even the unburied (in the form of cremated remains) make their presence known throughout Calgary's landscape.

Fig. 6: Queens Park Cemetery with Houses in the Background, 2008 (Photo by Keith Boyd)

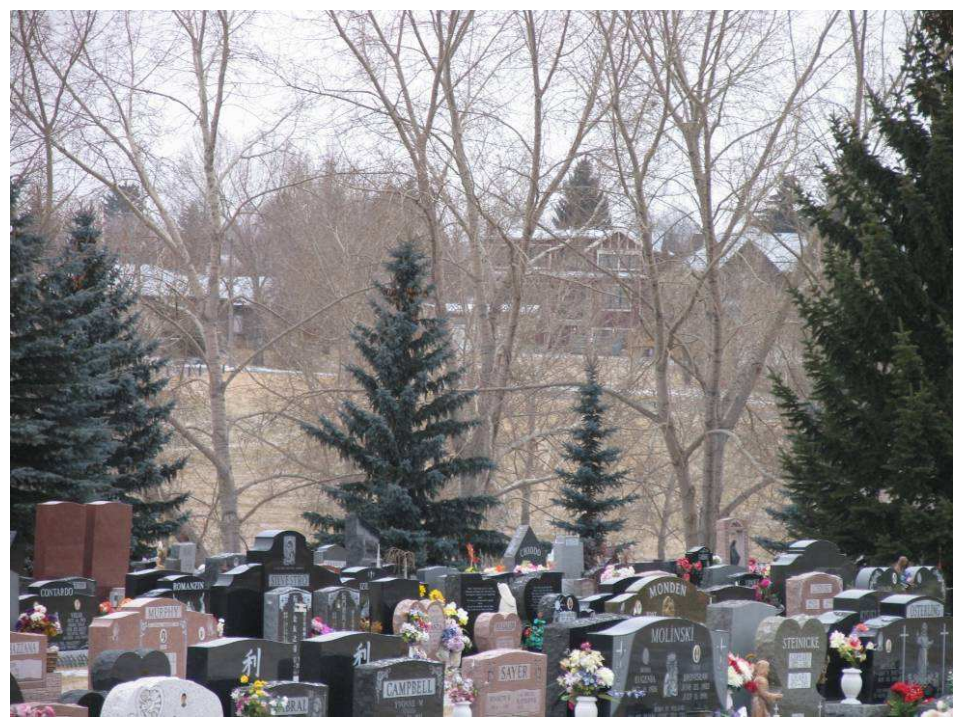

Through their undeniable presence and proximity, Van Herk's cemeteries maintain their educative function not by countering the city's ill effects, but rather by awakening citizens to the dynamics of the urban environment that they have created. The speaker of the poem acknowledges that the word "cemetery" derives from the Greek word "Koimeterion," 45 the root of which is koimaein, meaning "to put to sleep." restful. Instead, readers discover graves "elbowing each other awake," suggesting that these spaces facilitate an awakening consciousness within the city. ${ }^{47}$ van Herk's cemeteries reflect the constructed nature of Calgary's sprawl and the alienating and depersonalizing effects that this urban environment has on its inhabitants. The individual graves of van Herk's Calgary tell one another to "move over" in their desire for individual property and demarcated space, just as the demand for single-family dwellings means that Calgarians become increasingly isolated in their sprawling suburbs, as residents "fenc[e] / houses from themselves and each other, the neat divisions of denizens." ${ }^{48}$ The individual structures of "angular and affronted frame houses jutting roofs into the acrid sky" create a deathly image, the sign of Calgary's sprawl as it spreads across the horizon and evokes endless rows of headstones. ${ }^{49}$ (See Fig. 7)

Visually, the rapidly expanding city seems troubling in its uniformity, and van Herk emphasizes the isolating and confounding effects of this nondescript urban environment through the model of an equally confusing cemetery landscape. For instance, in the Chinese Cemetery "tombstones / . . / lean against each other in the eerie spool of headlights / searching through their maze." ${ }^{50}$ The beaming headlights of cars driving down the MacLeod Trail as they pass by the cemetery operate as a kind of spool of thread, promising safe passage through a constructed urban maze reminiscent of the experience of Theseus and the Minotaur. The concrete, stone, and asphalt 
environment of Calgary makes it difficult to navigate with the lack of distinct visual points of reference, and the city emerges as unvarying and confounding as the layout and appearance of a cemetery. (See Fig. 8)

Fig. 7: City Sprawl - North view from Petro Canada East, Calgary, 2007 (Photo by Tricia Antonini)

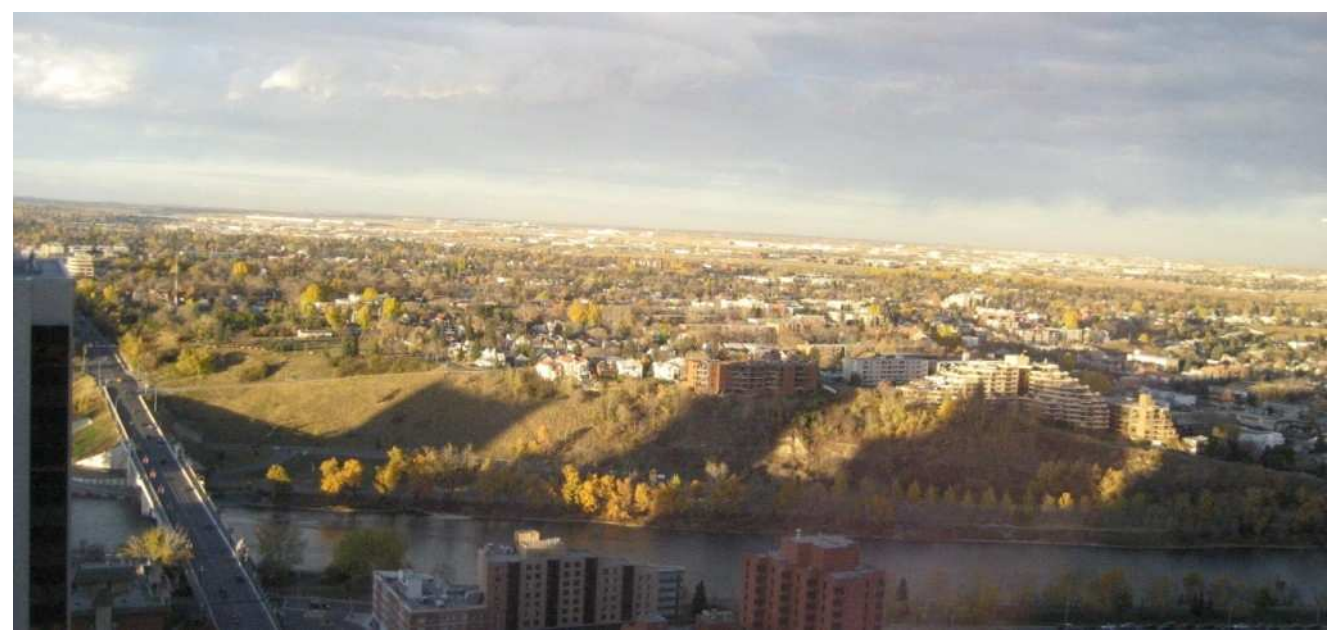

Fig 8: The Uniformity of Headstones as Exhibited in Mont Royal Cemetery, Montreal, 2007 (Photo by Shelley Boyd)

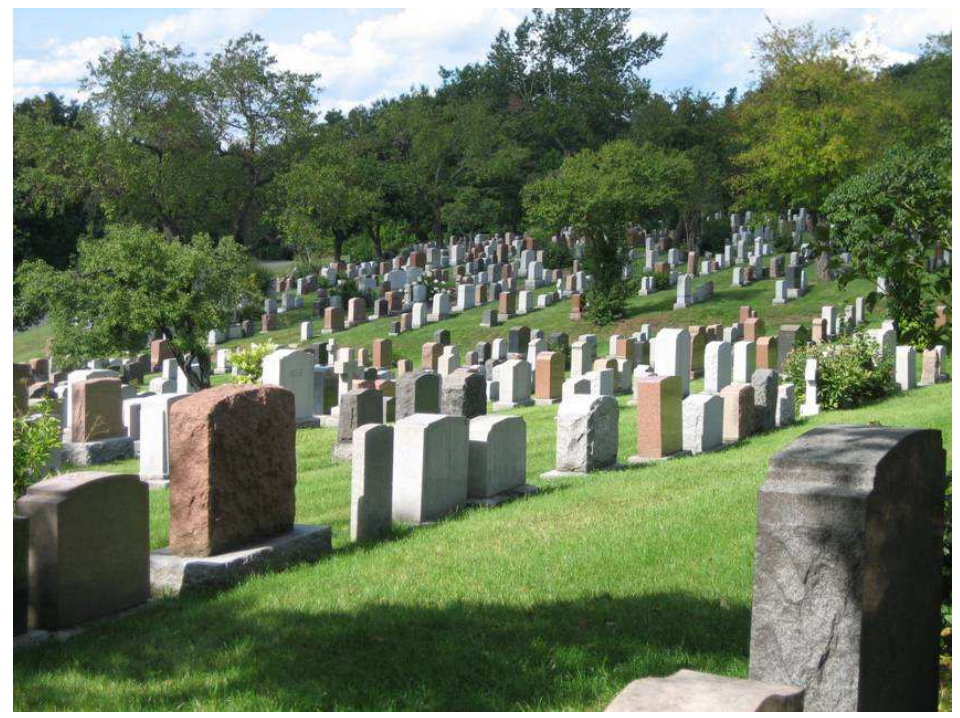

Calgarians must "consult a map" and navigate the quadrants of the city prior to driving home, just as they require section, row, and plot numbers in order to locate the resting place of a deceased individual. ${ }^{52}$ In Calgary, the four quarters of the city are subdivided repeatedly until street "names are picked up from the subdivisions." 53 At a loss, the speaker finally instructs, "How to find yourself: see map." ${ }^{54}$ Both city and cemetery are veritable mazes, labyrinths that rise up, leaving citizens lost and 
confused, unable to locate themselves within the very structures they have built. Ironically, the sprawling environment effaces individuality even as it is built to house individuals in separate family units.

The comparison between city and cemetery reaches beyond the mere physical composition of the urban environment, as Calgary's use of space impacts the behaviour and lives of its citizens. Not only do Calgarians face confusion in the labyrinth of the concrete city, but they also become increasingly isolated. Calgary's urban structures, such as the expanses of single-family dwellings and endlessly expanding roadways, house and transport individuals en masse, rather than foster integrated communities and connections between people. The consequence of this isolating urban sprawl is that Calgarians live primarily in their vehicles, separated and closed off from each other in their restrictive roles of frustrated commuters. In van Herk's city of over "3000 kilometers of paved road," Calgarians become de-humanized and depersonalized, transforming into ghostly "denizens of automobiles, grinding their teeth" as they "drive up and down the trails." ${ }^{56}$ The result is the effacement of Calgary's residents who briefly declare themselves in bumper stickers or personalized license plates such as "ZZZAP" and "MBA;" these are the markers of identities and accomplishments communicated in a few short words much like the engravings on headstones. ${ }^{58}$ Unfortunately, these rapid declarations of the self on Calgary's busy roadways are emptied of meaning because of the lack of a tangible human presence, personality, or social context. The limitations of these license plates are similar to that of engravings of headstones which potentially lose not just their permanence (through erosion or damage) but also their significance, as the memories of the deceased fade as those who knew them also pass away over time. Cemeteries may serve as repositories of Calgary's urban social history, but the speaker observes, "Recorded history not in the austere and polite / markers (granite, sandstone, marble, fieldstone) but the / promise of names held and used and recorded)." ${ }^{, 59}$ The past is dependent upon a continued relationship with the present, as the past only maintains its relevance by being actively appreciated, utilized, and preserved by the living.

Just as Calgary's suburban sprawl with its individual houses and automobile culture continues to develop in the manner of a growing graveyard, Calgary's downtown core generates a similarly ominous kind of experience for its citizens. (See Fig. 9) In van Herk's depiction of an economically depressed Calgary, the skyscrapers stand like "Grit-blown monoliths," ${ }^{60}$ and the downtown core teems with "half-finished buildings" as "struts and ceilings between gaping floors" hang like exposed "skeletons." Ultimately, what this downtown loses in its concrete, glass environment is the warmth of humanity, the love and desire that connect living people. In a section of van Herk's text that recalls the premise of Andrew Marvell's poem "To His Coy Mistress"-in which the male suitor states, "The grave's a fine and private place / But none, I think, do there embrace" ${ }^{\prime 2}$ — van Herk's speaker comments that in Calgary "You begin to look for lovers in these labyrinths" but the anonymity and confounding isolation of this figurative urban cemetery results in no connections. "[S]ex is too playful" for Calgary, ${ }^{64}$ the speaker tells us, and the "plus 15s" (the glass walkways that are situated 15 feet above street level and link the many buildings of downtown) appear as "ghostly vaginas" "drop into space and connect nothing," particularly when buildings stand half-finished with the sudden halting of construction. ${ }^{66}$ These macabre images evoke a lifeless and disturbing downtown core, but van Herk does not simply want to unsettle her readers as her "graveyard" offers a particularly compelling environment for reflection on the nature of Calgary: a place where

generations of citizens aspire to the heights of human achievement through their building, working, and striving, only to witness their ambitions and desires thwarted by the impermanence and unreliability of their urban world. 
Fig. 9: Esso Plaza with Bow Valley Sun Life Reflection and a Plus-15 Glass Walkway at the Bottom, Calgary, 2007 (Photo by Tricia Antonini)

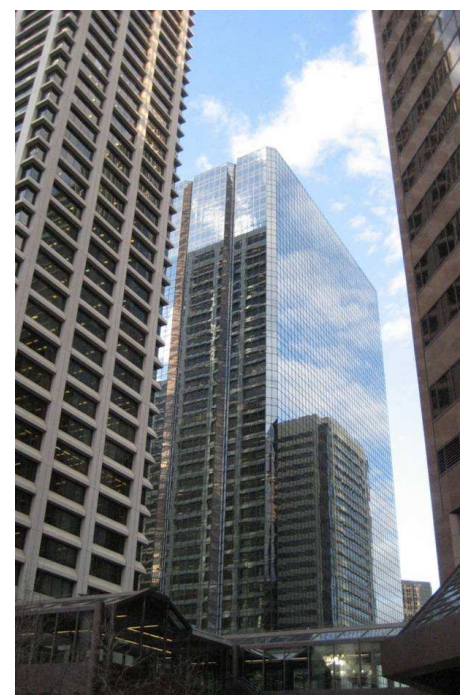

In van Herk's poem, Calgarians experience the dramatic rise and fall of their city through its highly changeable urban nature that cannot escape its grounding in material reality. During times of economic robustness, houses practically "floo[r] themselves," yet this furious laying-down of floorboards also suggests a fallen state, as the speaker comments that this growth paradoxically floors itself "into Babel." ${ }^{\circ 7}$ The speaker further describes the city with its stone and concrete as a veritable Jericho, a fortified city ready to crumble once the shouting begins, or the economy collapses. Through these biblical allusions, van Herk bestows archetypal status upon Calgary; it appears as a near-divine aspiration or sacred city: solid and infallible. But as with any human project, Calgary is flawed and impermanent. Van Herk's speaker questions, therefore, the quality of Calgary's upward "growth," its aspirations and achievements, as the state of the city and its culture seem bent on economic advantage, rather than on higher ideals. When looking up "Galleries" in the phonebook, the speaker notes that "under art, the two artists proudly listed in / 1910 are commercial and designer now." With commercial art superceding all other kinds of art because of its present value and utility, "Scenic artists [have] vanished utterly, scenes too." ${ }^{69}$ The tremendous historical growth of Calgary's infrastructure and economy means the effacement of not only fine art, but also the very natural surroundings that potentially inspire its creation.

In light of the problematic quality of Calgary's upward growth and social evolutions, the placement of particular cemeteries provides an important critical standpoint when viewing the downtown core. In her poem, van Herk makes explicit mention of Queens Park Cemetery and Union Cemetery, which in being situated either relatively close to, or within view of, the city's downtown exchange "Heights for the depths," (as these places afford visitors critical insight into their urban nature and locale. ${ }^{70}$ (See Figs. 10-11) Through its vantage point, Queens Park provides a new perspective to citizens who are continually climbing and aspiring to the height of success as exhibited through Calgary's towering skyscrapers. By grounding its citizens both literally (by burying them) and figuratively (by bringing them back down to earth), Queens Park serves as a grave garden of somber reflection on the temporal and qualitative limitations of human endeavour. This cemetery at first disorients, then redirects Calgarians' sense of their impermanent selves and their uncertain city, as the speaker concludes with the tongue-in-cheek remark that "gravity does that to you.", As in the manner of the city's downtown, cemeteries like Queens Park and Union, with their 
conspicuous elevation and constructed aspect, highlight the sometimes excessive human need for self-promotion and self-preservation, both of which hinge upon the desire to cheat death through the (false) realization of a permanent or transcendent state.

Paradoxically then, as much as Calgary seems neglectful and disrespectful of the past by paving over cemeteries in its focus on present and future growth, it is the transitory nature of the city - its defining cycles of decline, loss, and renewal - that mark this city as a place intimately connected to the passage of time. In the glass environment of downtown Calgary, the towers replicate images of themselves through their reflections, and in van Herk's interpretation these glass structures "bounce measured hours of sunlight from their golden glass and stand for death, another Stonehenge." 72 This comparison to Stonehenge recalls an earlier description of Queens Park Cemetery, with "the acres and acres of henges stoning themselves / up the hills." 73 (See Fig. 12) Through these references to Stonehenge, van Herk reveals that her discussion of Calgary is not wholly negative with respect to this constructed environment, but rather appreciative and, at times, even reverent. In his discussion of memorial architecture, Worpole writes, "While Stonehenge was not a burial site as far as is known, as a collection of standing stones it is part of a culture that placed large stones in the landscape as a means of connecting one world to another." ${ }^{, 74}$ With its tombstones hanging in suspension like "henges" and with its downtown skyscrapers rising ominously above the horizon, van Herk's Calgary is a city that, while problematic in its alienating sprawl, depersonalization, and artificiality, nevertheless represents the most human of experiences - that is, the passing of time and the related processes of growth and decay. This legacy of intense and ongoing change indelibly connects Calgary with the past and the city's former versions of itself.

The cemetery garden as a model for Calgary illuminates, therefore, the surprisingly "organic" nature of the city and its constructed environment. Van Herk actually describes the renovations to the city's landscape through the language of the garden. Calgary may not grow with the natural sunlight, yet the city as a figurative garden cemetery responds to "seasons of money" and undergoes its own cycles of change. ${ }^{75}$ This organic, garden imagery foregrounds the city's continued relationship with the past, as the city recreates itself out of the remains of its former identities. When entrepreneurial residents rename their local businesses, the new names operate as "offshoots" of the old. $^{76}$ Readers witness a different kind of city taking root across the successive generations as "Shoe leather. Tanneries have given way to tanning salons / (despite 2207 hours of shine per year)."77 Here, one of Calgary's prominent western identities as a "cow town" filled with cattle ranchers who earn a living through the selling of meat and hides is superceded by a world of suburbanites who opt for skin treatments of their own with the purchasing of fake tans.

The culture and personality of the city changes over time, but it is precisely during periods of immense growth that Calgary becomes, paradoxically enough, most deathly. With the rapid construction and exchange of real-estate, "houses [are] bought and sold and never lived / in." 78 The enjambment of the line intimates that property purchased solely for financial speculation (particularly during Calgary's real-estate crash of the 1980s) exists without residents and is ultimately devoid of life. Van Herk intimates, however, that during future upturns in the economy, the rapid development and the endless construction that accompanies it will continue to create an environment that seemingly cannot support life, as "the [construction] cranes wait for / another boom to announce itself, another graveyard to rear headstones." (S9 (See Fig. 13) With the verb "to rear" meaning "to promote or cause the growth of (plants)," "[t]o bring (a thing) to . . . a vertical position," "[t]o raise from the dead," or "[t]o rouse from bed or sleep," van Herk intimates that the future construction of a growing boom-time Calgary will, paradoxically, be a period of decrement, as graves, both real and figurative, will increase in number, highlighting yet again the problematic nature of an urban environment that confounds its citizens with its unvarying surroundings even as it recreates itself out of its former remains. ${ }^{80}$ 
Figs. 10-11: Union Cemetery with Calgary's Downtown Core in the Background, 2008 (Photos by Keith Boyd)
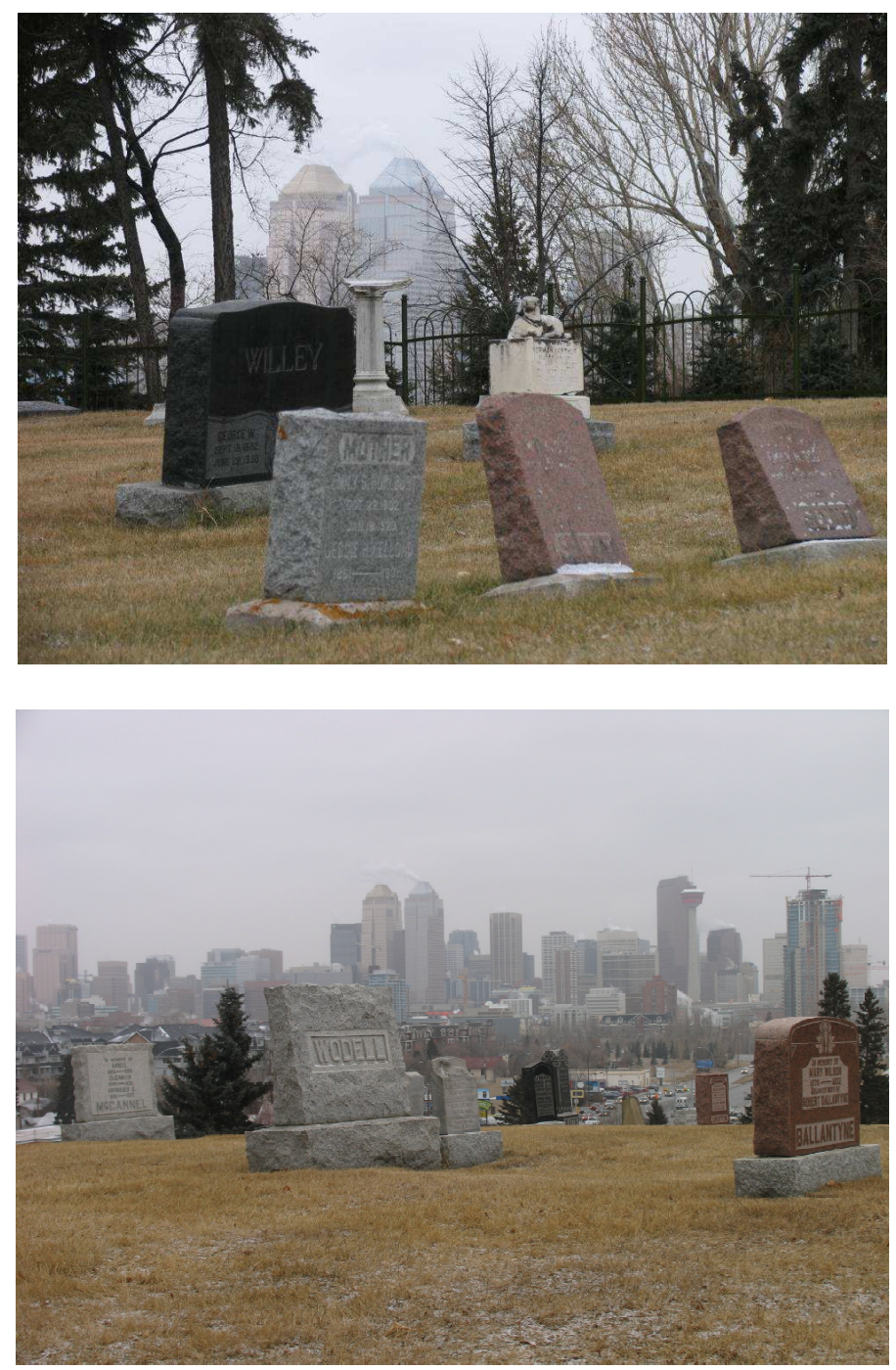

In her poem, van Herk admits that "it's death that makes a place its own" and that a "city is counted for the people who die there and who stay," but for van Herk even death lacks a certain permanence within an ever-fluctuating city. ${ }^{81}$ In a city known for its dynamic population growth and decline due to a changing economy, there are a few residents who decide to be buried in Calgary, "to implant [themselves] firmly and / say "Here I stay. . ." 82 This lack of permanent "residency" further advances van Herk's comparison of Calgary to a cemetery. Just as Calgary demands a transient, changeable nature, so too does death. Van Herk's speaker insinuates that Calgary's suburban homes are never lived in; similarly, "Graves are for their visitors. Residents beware." ${ }^{83}$ For van Herk, graves facilitate the last and most mysterious migration in a city known for its migrations. Indeed, in an interview, van Herk reflects on death and suggests that it is related to immigration and the imagining of an alternative kind of life: 'In order to immigrate you have to imagine how to do it. You can't know what it will be like; you have to imagine. . . . It seems to me that death is really tied to that, too, because it's a sort of final journey. Death is a final act of immigration: you become a different citizen." "In van Herk's poem, buried Calgarians "can only leave into light / burst through dark soil," 
as their next migration or transformation is a return to the garden from underground. "To leave" is both to move on to another place and to grow into something else. These processes of movement and change as they relate to death are intrinsic to the nature of Calgary and its legacy of recreating itself:

Desert nomads, transient denizens. Arriving and leaving, citizens of their own rules:

Ex-mounties

Ex-speculators

Ex-Metis buffalo hunters

Ex-arrivals ${ }^{86}$

Just as van Herk's "awake" graves in her cemeteries fail to create a sleeping world of permanent rest, Calgary, with its transient residents, becomes a city known for its "Restlessness"-its arrivals and departures. $^{87}$

Fig. 12: Headstones, or "Henges," Working Their Way up a Hill in Queens Park Cemetery, 2008 (Photo by Keith Boyd)

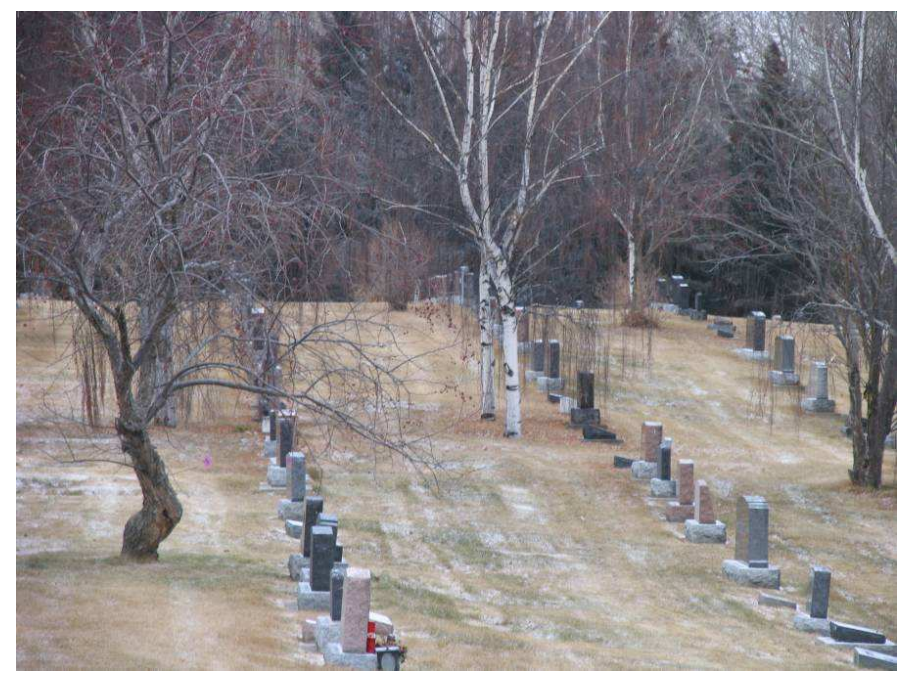

The continued relevance of van Herk's poem suggests that her cemetery model captures the very nature of the urban as she traces and even foretells Calgary's demise and numerous reincarnations. A cemetery may be a morbid model for a city, but as van Herk observes, "[H]umans need graves to remind themselves of their inevitable connection with the earth." 88 Calgary is an alienating, highly constructed place in van Herk's poem, but as a figurative garden cemetery, this city actually grounds its residents by revealing the transient nature of life- a realization writ large in the dynamic and surprisingly "organic" urban environment. The seemingly artificial surroundings of the city make Calgarians seem protected and separated from the natural cycles of time, but van Herk reveals that both the environments that citizens create and their behaviour within these spaces speak to their own intimate relationship with death and the past. 
Fig 13: "Keeping up with the Tall Guys," Calgary, 2007 (Photo by Tricia Antonini)

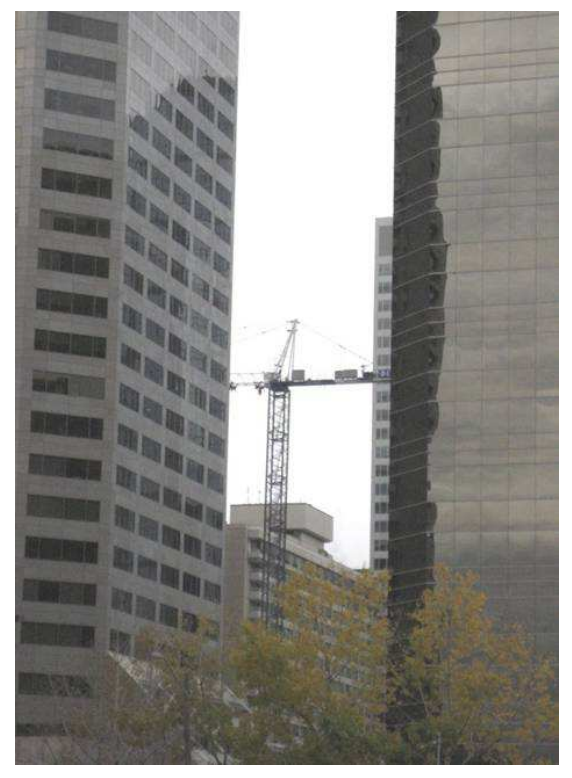

For contemporary readers, van Herk's long poem foretells the fact that Calgary's supposedly unstoppable present-day growth has its limits and consequences, as this evermore sprawling urban centre sheds light on the human condition: that is, our isolation, vulnerability, and eventual effacement with respect to time and space. Not surprisingly, then, van Herk's poem resonates with recent characterizations of Calgary's burgeoning landscape. In 2006, Globe and Mail architecture critic Lisa Rochon wrote that the suburban growth of Calgary is "unsustainable" and urged designers and urban planners to rethink the city or "Calgary's downtown will die a slow, heart-stopping death" even in boom-time. ${ }^{89}$ Fearing that "too many towers will further depersonalize the city centre," Rochon urges the promotion of foot traffic at street level and notes that the plus $15 \mathrm{~s}$ connect buildings, but not people. ${ }^{90}$ With Calgary being an ever-expanding "'temple of sprawl," non-profit groups are now lobbying civic leaders "for a new era of development meant to humanize this increasingly car-dependent city" and to construct a different kind of Calgary, another re-creation. ${ }^{91}$ Calgary's exponential growth is difficult to handle and the rapid development of its landscape leads to problematic effects on the environment and the social dynamic of the city. There are, of course, some signs of change: there is a push to build "sustainable villages," or high-density suburbs, ${ }^{22}$ and the City of Calgary has "gone green" in its own operations by using sustainable forms of energy. ${ }^{93}$ Rochon also applauds the innovative plans for "sky gardens," communal interior spaces (designed by architect Sir Norman Foster) that are part of the future construction of a 59-storey office tower for Encana Corporation (a natural gas company). ${ }^{94}$ Interestingly, this concept of a "sky garden" captures Calgarians' continuing desire for upward growth and their potential lack of "gravity," which, in the context of van Herk's poem, the cemetery affords at ground level.

Even when it appears at its most artificial, a city such as Calgary brings into focus the "naturalness" and fallibility of the environments that humans construct. By the conclusion of her poem, van Herk undermines the city's illusion of permanence by confounding the organic and 
inorganic when the speaker points to fossils embedded in the walls of Calgary's older downtown buildings. In the "architect's drawing of place" the "Brachiopods shine through" as a testament to the fact that whether it is a living creature or a built structure, all things are susceptible to the flux of time and change, the volatile cycles of growth, decay, and transformation. ${ }^{95}$ The brachiopods remind van Herk's readers of the fossil fuels that have sustained Calgary's economy in the past and continue to drive it today. With its immense office buildings towering into the heavens and housing Canada's oil industry, Calgary exists in the very manner that is does because of its dependence on an extinct prehistoric world, a relationship that forces Calgarians to be cognizant of their own temporality. (See Fig. 14) In her final lines, van Herk addresses her readers as fellow Calgarians, declaring that "you too [are] sheathed in prehistoric stone" and Calgary's mighty buildings are but "the gravestones of Jericho before the walls tumble down" upon you. ${ }^{96}$ Whether we live within this city or not, we are all, in a sense, Calgarians, in van Herk's final estimation, as our human desire for permanence and selfdemarcation must inevitably give way to our fundamental connection with the earth.

Fig 14: TCPL Tower with Petro Canada Reflection, Calgary, 2007 (Photo by Tricia Antonini)

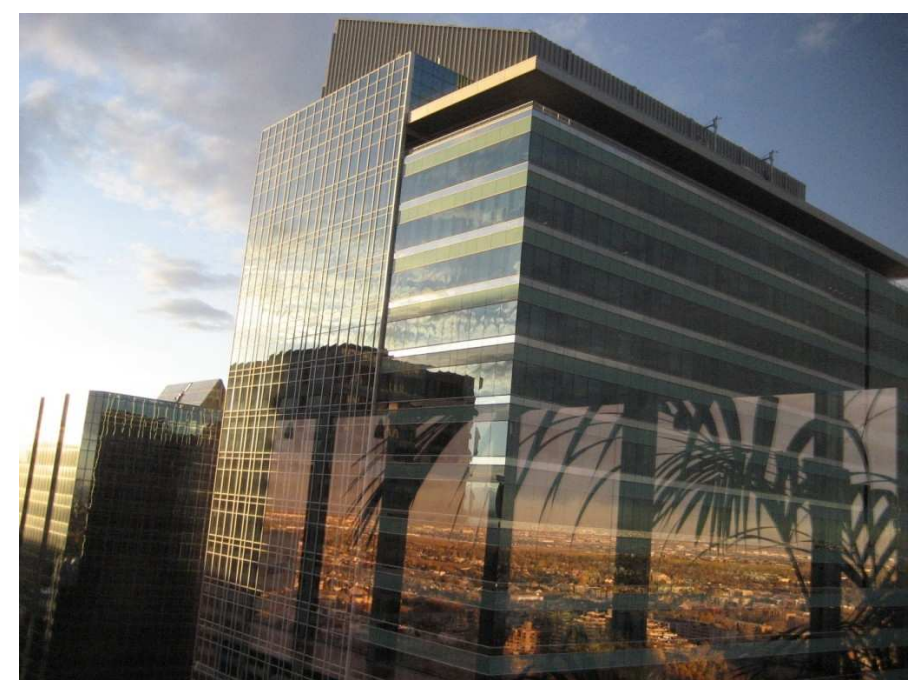

\footnotetext{
${ }^{1}$ Schoffield, "Ontario Left Behind in Jobs Boom," B5.

2 Whyte, "Calgary - Turning into Toronto?"

${ }^{3}$ In September 2006, Murray Whyte of the Toronto Star noted that Calgary's current size was 745 square kilometres, and that the city was expected to grow to 847 square kilometers in 2007, making Calgary larger than Toronto (which is 630 square kilometres) and about the same size as New York and its five boroughs (even though New York has a population of 12 million people) (Whyte). In addition to its spatial size, Chris Turner revealed in the fall of 2007 that Calgary has "the largest per-capita ecological footprint of any municipality in Canada," as it "takes 9.86 global hectares (gha) of land and water to provision your average Calgarian-well above the national average of 7.25 gha (which itself places Canada near the top of most worldwide rankings)" (F1).

${ }^{4}$ Curl, "John Claudius Loudon,” 138.

${ }^{5}$ Quoted in Curl, 141.
} 
${ }^{6}$ Francis, et al., The Secret Cemetery, 6-7.

7 "God's Acre," Oxford English Dictionary Online.

${ }^{8}$ Young, Respectable Burial, 19.

${ }^{9}$ Ibid., 16.

${ }^{10}$ Martin, A History of Canadian Gardening, 75.

11 "Cemeteries," The City of Calgary.

12 van Herk, "Grave Thoughts," 54.

${ }^{13}$ Young, Respectable Burial, 16.

${ }^{14}$ Ibid.

${ }^{15}$ Ibid., 70. Young quotes the letter at length: "'Montreal is destitute of parks, gardens or pleasure grounds. Our peaceable and respectable mechanics and operative classes have no time to visit these grounds on week days, and if shut out during our short summer Sundays their whole beauty and refining influence is lost to them. This loss is a direct injury to the whole community, for I defy any man to leave these grounds, after a visit with his wife or family, without carrying with him or with this family more hallowed and refining influences" (70).

${ }_{16}$ Worpole, Last Landscapes, 30.

17 Ibid.

${ }^{18}$ Govier, "The Land of Beginning Again," 24.

19 "Chinese Cemetery," The City of Calgary.

${ }^{20}$ Worpole, Last Landscapes, 31

${ }^{21}$ Francis, et al., The Secret Cemetery, 7.

22 Ibid., xvii.

${ }^{23}$ Ibid., 104.

${ }^{24}$ Worpole, Last Landscapes, 91.

${ }^{25}$ van Herk, Calgary, 322.

${ }^{26}$ As Minister of the Interior for Wilfred Laurier's Liberal government, Clifford Sifton created a tremendously successful propaganda campaign for the settling of the western prairies; the West grew from a population of less than 300,000 in 1896, to over 1.5 million by 1914 (D. Francis 108). With its ever-increasing sprawl, Calgary today is a city that continues to resist high-density living. A 2006 Globe and Mail article revealed that, at the time, only about 30,000 people of Calgary's nearly one million residents lived in the city centre with the majority of the middle-class preferring suburbia (Rochon R3). ${ }^{27}$ Laird, "Search for Balance," 28.

${ }^{28}$ Toronto Star reporter Thomas Whyte noted in 2006 that "Calgary's high-speed development is now swallowing about 1.5 hectares a day. And it shows no signs of slowing" (Whyte).

${ }^{29}$ van Herk, Calgary, 323.

${ }^{30}$ Ibid.

${ }^{31}$ Ibid., 322.

32 Ibid., 321.

${ }^{33}$ Ibid., 322.

${ }^{34}$ Ibid., 324.

35 Ibid.

36 Ibid.

${ }^{37}$ When considering van Herk's pairing of the grave and garden, readers may find it interesting to know that the word "grave" once had a gardening denotation and referred to "a trench for earthing up potatoes and other roots" ("grave"). 38 Ibid., 326.

${ }^{39}$ Ibid.

${ }^{40}$ Ibid., 324.

${ }^{41}$ Ibid., 322.

42 Ibid.

${ }^{43}$ Ibid., 323.

${ }_{44}^{4}$ Ibid., 324.

${ }^{45}$ Ibid., 322.

${ }^{46}$ Ibid., 341.

${ }^{47}$ Ibid., 322.

${ }^{48}$ Ibid., 332.

49 Ibid.

${ }^{50}$ Ibid., 323.

${ }^{51}$ Ibid., 334. 
52 Ibid., 324.

${ }^{53}$ Ibid., 336. Govier similarly addresses the confusing layout of Calgary's sprawling suburbs and the process of naming that helps residents to locate themselves: "In its suburban districts, the residential streets circle and bisect each other in a madman's geometry. But developers kindly gave all the streets in a given area names beginning with the same letter. If it starts with B, it's Brentwood. E is for Eagle Ridge and P is for Parkland" (24).

${ }^{54}$ van Herk, Calgary, 336.

55 Ibid., 339.

56 Ibid., 332.

${ }^{57}$ Ibid.

${ }^{58}$ Ibid.

${ }^{59}$ Ibid., 323.

${ }^{60}$ Ibid., 329.

${ }^{61}$ Ibid., 334.

62 Marvell, "To His Coy Mistress," 31-32.

${ }^{63}$ van Herk, Calgary, 338.

${ }^{64}$ Ibid., 339.

${ }^{65}$ Ibid., 338.

${ }^{66}$ Ibid., 339.

${ }^{67}$ Ibid., 328.

${ }^{68}$ Ibid., 326.

${ }^{69}$ Ibid., 326.

${ }^{70}$ Ibid., 322.

${ }^{71}$ Ibid., 323.

72 Ibid., 329.

${ }^{73}$ Ibid., 322.

${ }^{74}$ Worpole, Last Landscapes, 100.

${ }^{75}$ van Herk, Calgary, 328.

${ }^{76}$ Ibid., 325.

${ }_{77}$ Ibid., 326.

78 Ibid., 328.

${ }^{79}$ Ibid., 329-30, emphasis added. Construction cranes have a long-standing presence in the urban landscape and culture of Calgary, and will continue to be a feature with developers' predictions that 100 thirty-storey condominiums and 20 thirty-story office towers will be built by 2025 (Rochon R3). Reflecting on Calgary's many transformations in 1988, Tom Fennell notes, "In the early 1980s, when their city's economy was booming, Calgarians jokingly adopted the 'sky crane' as their official bird. The construction cranes soared from dozens of building sites in the city during the energy boom that ended when oil prices nose-dived in 1983" (28).

80 "rear," Oxford English Dictionary Online.

81 van Herk, Calgary, 321.

82 Ibid., 324.

${ }^{83}$ Ibid., 321.

${ }^{84}$ Verduyn, "The Grace of Living and Writing," 18.

85 van Herk, Calgary, 319.

${ }^{86}$ Ibid., 331.

${ }^{87}$ Ibid., 333.

${ }^{88}$ van Herk, "Grave Thoughts," 54.

${ }^{89}$ Rochon, "Time to Get Tough on Cowtown," R3.

${ }^{90}$ Ibid.

${ }^{91}$ Whyte, "Calgary - Turning into Toronto?"

${ }^{92}$ Ibid.,

${ }^{93}$ Turner, "The Secret Greening of Calgary," F1.

${ }^{94}$ Rochon, "Time to Get Tough on Cowtown," R3.

${ }^{95}$ van Herk, Calgary, 340.

${ }^{96}$ Ibid. 


\section{Bibliography}

"cemetery." Oxford English Dictionary Online. http://dictionary.oed.com (accessed Nov. 6, 2007).

"Cemeteries." The City of Calgary.

http://content.calgary.ca/CCA/City+Hall/Business+Units/Parks/Cemeteries/Index.htm (accessed Oct. 11, 2007).

"Chinese Cemetery." The City of Calgary.

http://content.calgary.ca/CCA/City+Hall/Business+Units/Parks/Cemeteries/Cemetery+Loc ation/Chinese+Cemetery.htm (accessed Oct. 11, 2007).

Curl, James Stevens. "John Claudius Loudon and the Garden Cemetery Movement." Garden History 11.2 (1983): 133-56.

Fennell, Tom. “How a Cow Town Grew Up.” Maclean's, Feb. 15, 1988. 28-30.

Francis, Doris, Leonie Kellaher, and Georgina Neophytou. The Secret Cemetery. Oxford: Bert, 2005.

Francis, Douglas R. “The Promised Land: The Utopian West 1880-1920.” Images of the West: Responses to the Canadian Prairies. Saskatoon: Western Producer Prairie Books, 1989. 107-27.

"God's acre." Oxford English Dictionary Online. http://dictionary.oed.com (accessed Aug. 13, 2008).

Govier, Katherine. "The Land of Beginning Again.” Maclean's, Feb. 15, 1988. 24-25.

"grave." Oxford English Dictionary Online. http:/ / dictionary.oed.com (accessed Nov. 6, 2007).

"graveyard." Oxford English Dictionary Online. http://dictionary.oed.com (accessed Nov. 6, 2007).

"grotto." Oxford English Dictionary Online. http://dictionary.oed.com (accessed Nov. 6, 2007).

Laird, Gordon. "Search for Balance." Maclean's, Jun. 3, 2002. 28.

Martin, Carol. A History of Canadian Gardening. Toronto: McArthur, 2000.

Marvell, Andrew. "To His Coy Mistress." The Norton Anthology of Poetry. Shorter fourth ed. Ed.

Margaret Ferguson, Mary Jo Salter, and Jon Stallworthy. New York: Norton, 1997. 271-72.

"rear." Oxford English Dictionary Online. http://dictionary.oed.com (accessed Nov. 6, 2007).

Rochon, Lisa. "Time to Get Tough on Cowtown." Globe and Mail, Nov. 8, 2006. R3.

Schoffield, Heather. "Ontario Left Behind in Jobs Boom." Globe and Mail, Nov. 4, 2006. B5.

Turner, Chris. "The Secret Greening of Calgary." Globe and Mail, Sept. 15, 2007. F1.

Van Herk, Aritha. Calgary, This Growing Graveyard. A/Long Prairie Lines: An Anthology of Long Prairie

Poems. Ed. Daniel S. Lenoski. Winnipeg: Turnstone, 1989. 319-43.

. Calgary, This Growing Graveyard. NeW est Review 13.4 (Dec. 1987): 5-11.

" "Grave Thoughts." Canadian Geographic, Sept./Oct. 1998. 54.

Verduyn, Christl. "The Grace of Living and Writing." Aritha van Herk: Essays on Her Works. Ed. Verduyn. Toronto: Guernica, 2001. 15-30.

Whyte, Murray. "Calgary - Turning into Toronto?” Toronto Star, Sept. 2, 2006. Active Transportation Listserv http://atlistserv.goforgreen.ca/2006/09/calgary-turning-into-toronto.html (accessed Oct. 15, 2007).

Worpole, Ken. Last Landscapes: The Architecture of the Cemetery in the West. London: Reaktion, 2003.

Young, Brian. Respectable Burial: Montreal's Mount Royal Cemetery. Montreal and Kingston: McGillQueen's UP, 2003. 